\title{
Literature Review: Strategi Promosi Rokok Versus Strategi Promosi Kesehatan Anti Rokok
}

\section{Literature Review: Cigarette Promotion Strategies Versus Anti-Smoking Health Promotion Strategies}

\author{
Havizoh $^{1}$, Widyatuti ${ }^{2}$ \\ Fakultas Ilmu Keperawatan, Universitas Indonesia, Indonesia
}

\section{ARTICLE INFO}

\section{Article history}

Received date

03 August 2020

Revised date

10 August 2020

27 August 2020

Accepted date

07 Oct 2020

Keywords:

Cigarette;

Promotion;

Teenagers.

Kata kunci:

Rokok;

Promosi;

Remaja.

\begin{abstract}
ABSTRAK
Globally, the amount of loss due to smoking has been well documented. But smoking among teenagers not only dwells on the problem of physical danger in the form of illness or death but also damages emotions and behavior. The phenomenon of smoking among adolescents takes attention because the future of a nation is determined by the quality of its future generations. This paper focuses on understanding cigarette promotion strategies and juxtaposing them with anti-smoking health promotion strategies with the literature review method. The results show that there are gaps in themes and content where health promotion strategies are considered rigid and have not yet adapted to the development of millennial adolescents. The recommendations given should be that themes and content in health promotion be packaged more interactively and flexibly according to the current era. Incorporating elements of anti-smoking health promotion into the game features will allow health promotion to be more acceptable among teenagers.
\end{abstract}

\begin{abstract}
Besarnya kerugian akibat merokok telah tercatat dengan baik secara global. Namun merokok di kalangan remaja bukan hanya berkutat pada persoalan bahaya fisik berupa sakit atau kematian, tapi jugamerusak emosional dan perilaku. Fenomena merokok dikalangan remaja patut menjadi perhatian karena masa depan suatu bangsa ditentukan dengan kualitas generasi penerusnya.Tulisan ini berfokus pada memahami strategi promosi rokok dan menyandingkannya dengan strategi promosi kesehatan anti rokok yang ada dengan metode kajian pustaka. Hasil menunjukkan ada kesenjangan pada tema dan konten dimana strategi promosi kesehatan dinilai kakudan belum menyesuaikan dengan perkembangan remaja millennial. Rekomendasi yang diberikan hendaknya tema dan konten dalam promosi kesehatan dikemaslebih interaktif dan fleksibel disesuaikan dengan era kekinian. Memasukkan unsur promosi kesehatan antirokok ke dalam fitur game akan memungkinkan promosi kesehatan lebih diterima di kalangan remaja.
\end{abstract}

Corresponding Author:

Havizoh

Fakultas Ilmu Keperawatan, Universitas Indonesia, Indonesia

Email: havizoh@ui.ac.id

\section{PENDAHULUAN}

Merokok merupakan perilaku kesehatan berisiko yang belum dapat dientaskan hingga kini. Bagaikan jamur di musim hujan, jumlah perokok semakin bersemi. World Helath Organization (2015) melaporkan, Indonesia merupakan negara ketiga dengan jumlah perokok terbesar di dunia setelah Cina dan India dengan prevalensi perokok remaja tertinggi di dunia (Kusumawardani, et al., 2018). Data Survey Demografi Kesehatan Indonesia (Badan Pusat Statistik, 2017) menunjukkan $1 \%$ remaja perempuan merokok dan $55 \%$ remaja laki-laki merokok, dimana $30 \%$ remaja perempuan dan $21 \%$ remaja laki-laki mulai merokok dibawah 
umur 13 tahun dengan 50\% remaja laki-laki menghisap lebih dari 10 batang rokok perhari. Data ini menunjukkan bahwa remaja merupakan kelompok umur yang menyumbang jumlah perokok di Indonesia.

Fenomena merokok di kalangan remaja ini patut dikhawatirkan, mengingat bukan hanya meningkatkan risiko penyakit namun juga merusak emosional dan perilaku remaja, bahkan menjurus kepada perilaku kriminal. Berdasarkan hasil survey perilaku kesehatan pada anak usia sekolah atau Health Behaviour in School-aged Children (HBSC) ditemukan remaja merokok memiliki kebiasaan makan tidak sehat, kepuasan hidup yang rendah, perilaku mengintimidasi, inisiasi seksual dini, risiko cidera, dan keluhan kesehatan lainnya (World Helath Organization, 2016). Diperkuat (Wang, Hipp, Butts, \& Lakon, 2018) yang mengemukakan penggunaan rokok, alkohol dan ganja dalam konteks jejaring sosial berbasis sekolah mempunyai hubungan timbal balik. Remaja yang merokok akan lebih mungkin untuk mencoba minum alkohol dan memakai ganja, begitupun sebaliknya, sedangkan penggunaan napza berkaitan erat dengan kejahatan, pelecehan, prilaku bunuh diri,seks bebas, meningkatkan resiko HIV dan penyakit mental (Nebhinani \& Kuppili, 2018).

Maraknya fenomena merokok dikalangan remaja tidak terlepas dari gencarnya marketing perusahaan rokok dalam memarketkan produkproduk mereka secara apik di berbagai media. Pemasaran tembakau yang mencakup iklan dan upaya promosi seperti sponsor acara yang menarik kaum remaja, juga sangat signifikan terkait dengan inisiasi merokok dan kebiasaan merokok di kalangan remaja. Remaja yang terpapar dengan promosi dan penggambaran tembakau di media termasuk media internet memiliki sikap lebih cenderung mulai merokok (Escobedo, et al., 2018). Hal ini sejalan dengan data SDKI (2017) dimana $81 \%$ remaja perempuan dan $77 \%$ remaja laki-laki di Indonesia menonton televisi, $80 \%$ remaja perempuan dan $86 \%$ laki-laki mengakses internet (Badan Pusat Statistik, 2017).

Tingginya prevalensi penggunaan media di kalangan remaja seharusnya menjadi peluang besar bagi upaya promosi kesehatan termasuk pencegahan merokok. Berbagai upaya promosi telah dilakukan, namun angka merokok makin tinggi.

Tulisan ini bertujuan untuk menganalisis strategi perusahaan rokok dalam menggait perokok pemula dan membandingkannya dengan strategi promosi kesehatan anti rokok. Diharapkan dapat memberikan rekomendasi untuk memperkuat upaya promosi kesehatan sebagai kontra promosi iklan rokok.

Tulisan ini disusun menggunakan metode kajian literatur. Untuk mengumpulkan data berupa studi-studi, penulis menggunakan beberapa database online, diantaranya scopus sebanyak 5 artikel, proquest 3 artikel, wiley 1 artikel, ebsco 1 artikel, google scholar 2 artikel dan portal berita nasional. Penulis menggunakan beberapa kata kunci pencarian yaitu update smoking cessation, tobacco control, tobacco prevention, cigarette intervention, tobacco marketing strategies. Artikel juga dibatasi pada tahun terbit 2013-2020. Untuk penguatan materi, penulis juga mengambil referensi dari portal berita nasional dan beberapa buku text dengan kriteria penerbitan 10 tahun terakhir.

\section{PEMBAHASAN}

\section{Strategi Promosi Rokok}

Remaja merupakan kelompok umur yang menjadi target konsumen bagi perusahaan rokok. The Tobacco Control Atlas Asia Region menyebut perusahaan rokok berupaya mempromosikan produk dengan membidik remaja sebagai target pasar (Tan YL. and Dorotheo, 2018). Hal ini ditujukan untuk mengganti perokok dewasa yang meninggal akibat penyakit akibat tembakau. Perusahaan rokok memahami bahwa rokok mengandung senyawa nikotin yang dapat menimbulkan adiksi pada otak. Karena itu, upaya pemasaran difokuskan pada mengenalkan rokok pada generasi muda (World Helath Organization, 2015). Hal ini sejalan dengan pendapat Kotler and Amstrong (2012) bahwa sebuah produk tidak mungkin akan sampai ke tangan konsumen dan bahkan menjadi sangat populer dengan tanpa strategi promosi yang apik dan dikemas menarik.

Promosi rokok dilakukan secara massif. O'Brien, Navarro, dan Hoffman (2018) mengidentifikasi 62 brand rokok yang memiliki mobile website yang digunakan sebagai media promosi produk, sedangkan (Escobedo, et al., 2018) mengatakan ada ribuan situs dipakai sebagai media untuk menjual, memasarkan dan mempromosikan produk tembakau. Penelitian lainnya pada 388 merk tembakau dimana 108 darinya menjadi sponsor di Facebook (Jackler, Li, Cardiff, \& Ramamurthi, 2018). Di Indonesia, promosi bisa ditemukan di media televisi, koran, baliho-baliho yang terpasang di ruas jalan, hingga merambah ke media internet. Di televisi dapat dilihat bebas serta muncul berulang kali, baik 
saat commercial break maupun sponsor acara. Brand rokok ternama berlomba-lomba memasangkan iklan dengan berbagai konsep dan memilih waktu yang tepat pada program dengan rating tertinggi. Iklan rokok mudah ditemukan dalam bentuk baliho-baliho yang terpajang di sepanjang jalan umum.

Tema atau konten juga menjadi strategi utama marketing produk rokok. Dautzenberg B. (2018) mengungkapkan bahwa poin krusial yang perusahan rokok perhatikan dalam pemasarannya adalah konten yang bertemakanpenanaman nilai atau simbolisasi. Simbolisasi ditujukan untuk membangun imagebahwa merokok merupakan kebiasaan lelaki sejati, merokok adalah ritual untuk menjadi pria dewasa, rokok adalah teman setia saat stres dan bosan. Ketiga poin ini menjadi esensi iklan untuk mengubah pra perokok menjadi perokok pemula lalu menjadi perokok aktif. Escobedo, et al (2018) juga mengatakan situs web perokok dibuat dengan tema-tema positif dan dikombinasikan dengan konten interaktif. Tema-tema meliputi gaul, sukses, gaya hidup glamour, petualang, taste, diskon-diskon harga, dan inovasi, konten interaktif meliputi game, partisipasi dalam kontes, memilih kuponkupon, performa musik terkini, memilih musik sesuai selera dan informasi event atau agenda acara.

Simbolisasi atau penanaman nilai juga menjadi strategi pemasaran oleh industri rokok di Indonesia. Setidaknya ada tiga nilai yang diselipkan pada iklan rokok yang ditayangkan di media yakni keren, solidaritas dan maskulin. Nilai inilah yang signifikan berhubungan dengan persepsi dan perilaku merokok pada remaja yang semakin meningkat dan bergeser ke usia lebih dini (Bastonus \& Herieningsih, 2017; Djamil, 2017; Purnaningrum, Joebagio \& Murti, 2017).

\section{Memahami Strategi Promosi Kesehatan Pencegahan Merokok}

Perkembangan era 4.0 telah menggiring bidang kesehatan dalam pemanfaatan teknologi informasi dalam upaya promotif, preventif dan kuratif dan rehabilitatif (World Helath Organization, 2017). Dalam kaitan dengan upaya promosi kesehatan anti rokok, Das, Tonelli, \& Ziedonis (2016) menyebutkan ada beberapa situs yang menjadi support system promosi rokok, seperti website gratis smokefree.gov dengan pilihan yakni smokefreevet, smokefreewomen, smokefreeteen, smokefreeespanol, smokefree60+. Penulis, pada Januari 2020, lansung menelusuri laman web dan membuka smokefreeteen, dimana terdapat laman instagram smokefreeus dengan jumlah followers 3.887, facebook 11.491 dan twitter 20.974. Di Indonesia, web yang senada seperti Suara Tanpa Rokok memiliki follower instagram 40.900, twitter 4324 dan facebook 178.134. sedangkan situs lain yakni Indonesia Bebas Rokok, Upaya Berhenti Merokok. Namun, aktifitas yang ditemukan berisi kampanye bahaya rokok yang menyebabkan penyakit kronik atau kematian.

Penggunaan platform media sosial untuk promosi anti rokok semakin digalakkan. Jacobs, Cobb, Abroms, \& Graham (2014) menyebutkan hanya 9 akun komunitas di Facebook untuk dukungan promosi anti rokok, 7 aplikasi dilengkapi fitur interaksi, informasi dan sosial yang memungkinkan pengguna untuk saling bertukar cerita, dan membangun dukungan sosial untuk berhenti merokok. Namun kepatuhan terhadap komitmen berhenti merokok masih rendah.

Media pendukung berikutnya yakni pesan text atau SMS. Spohr, et al (2015), menganalisis 13 studi dan menemukan bahwa intervensi pendukung berhenti merokok dengan pesan text baru dilaksanakan di beberapa negara yakni Inggris, Amerika Serikat, Selandia Baru, Australia, Cina, Swiss, dan Turki. Bagi yang ingin berlangganan dengan fitur ini akan dikirimi pesan-pesan motivasi, edukasi bahaya rokok, dan manfaat bila tidak merokok. Hasilnya menunjukkan peningkatan $35 \%$ keberhasilan berhenti merokok, namun hanya tiga studi saja dengan sasaran remaja dan dewasa muda (Spohr, et al., 2015). Layanan pesan text lainnya seperti text2Quit dikenakan biaya $\$ 29.99$ untuk 4 bulan (Das, et al., 2016).

Borelli, et al. (2015) dalam penelitian cohort pada 1000 orang di US dan UK menemukan $93 \%$ perokok memiliki mobile phone dan $76 \%$ adalah jenis smartphone. Para perokok yang termotivasi untuk berhenti akan lebih terbantu dengan menggunakan ehealth atau mhealth, seperti smokefreebrain app, social local mobile (SoLoMo) app, smokefreebrain SoLoMo app mini games, quits smoking cessation nation, dan lain-lain (Borrelli, Bartlett, Tooley, Armitage, \& Wearden, 2015). Penulis menelusuri laman quits smoking cessation nation di playstore dan menemukan 6644 penilaian dimana $67,5 \%$ memberikan penilaian positif bahwa aplikasi ini sangat membantu dalam proses berhenti merokok. Namun tidak disebutkan lama waktu yang dibutuhkan tiap orang untuk berhenti total dan keterbatasan dalam mengakses data pribadi pengguna dan aplikasi ini tidak spesifik untuk pencegahan merokok pada remaja (Das, et al., 2016). 
Aplikasi permainan (game) merupakan ranah teknologi terbaru dalam dukungan berhenti merokok. Sebanyak $74,5 \%$ perokok hobi bermain video game atau social game dan dapat bermain lebih lama dari bukan perokok (Das, et al., 2016). Shabalina, Aleynikov, Davtian, Matokhina, \& Moffat (2017) telah mengajukan prototipe mobile game dengan metode yang berbeda, yakni dengan dialog virtual perokok dengan anaknya untuk membangkitkan emosi dengan ketakutan buah hati akan dampak yang akan menimpa orang tuanya yang perokok. Argumentasinya adalah seorang perokok mungkin akan kebal bila ditakut-takuti visualisasi atau informasi bahaya penyakit akibat merokok, namun tidak akan tahan dengan kesedihan anaknya. Namun, belum ada review mengenai game ini dan saat ditelusuri di playstore penulis belum menemukannya. Game pendukung berhenti merokok lainnya yakni inspired. Game ini mengusung metode manajemen kontingensi dimana peserta yang berhasil berhenti merokok akan diberikan insentif berupa uang. Dalam uji coba game ini diketahui $100 \%$ responden mengatakan game ini menarik, $71 \%$ berpendapat bahwa game ini akan membantu dalam program berhenti merokok (Raiff, Fortugno, Scherlis, \& Rapoza, 2018). Namun inspired game ini juga masih berbentuk prototipe awal, sehingga keefektifannya belum dapat dievaluasi lebih mendalam.

\section{Karakteristik Remaja}

Masa remaja merupakan masa transisi dari anak-anak menuju dewasa. Tugas perkembangan mental remaja difokuskan pada upaya meningkatkan dan menginternalisasikan sikap dan perilaku menuju kedewasaan (Allender et al., 2014). Proses transisi menyangkut perubahan pada fisik, psikologis, fungsi sosial dan maturitas seksual. Masa remaja merupakan waktu pencarian identitas dan kepribadian yang mandiri.

Penggunaan internet di Era 4.0 semakin menjadi kebutuhan bagi remaja. Fernández-deArroyabe-Olaortua, et al. (2018) dan Haug, Paz Castro, Wenger, \& Schaub (2018) mengatakan bahwa perkembangan teknologi informasi telah mengubah pola komunikasi dan tatanan hidup terutama generasi remaja. Remaja identik dengan 'generasi net' atau 'generasi millenial' dimana pemakaian smartphone dan konsumsi terhadap internet makin meningkat. Temuan menunjukkan bahwa youtube dan video game telah menjadi tulang punggung utama konsumsi dan kreasi bagi remaja laki-laki, dan remaja perempuan lebih suka mengambil foto dan video menggunakan smartphone dan membagikannya di jejaring sosial. Penggunaan internet di kalangan remaja untuk beberapa tujuan yaitu mengakses informasi, mencari konten-konten hiburan dan berinteraksi sosial. Hal ini menunjukkan bahwa remaja menyukai sesuatu yang baru, konten yang menghibur, dan interaktif. 


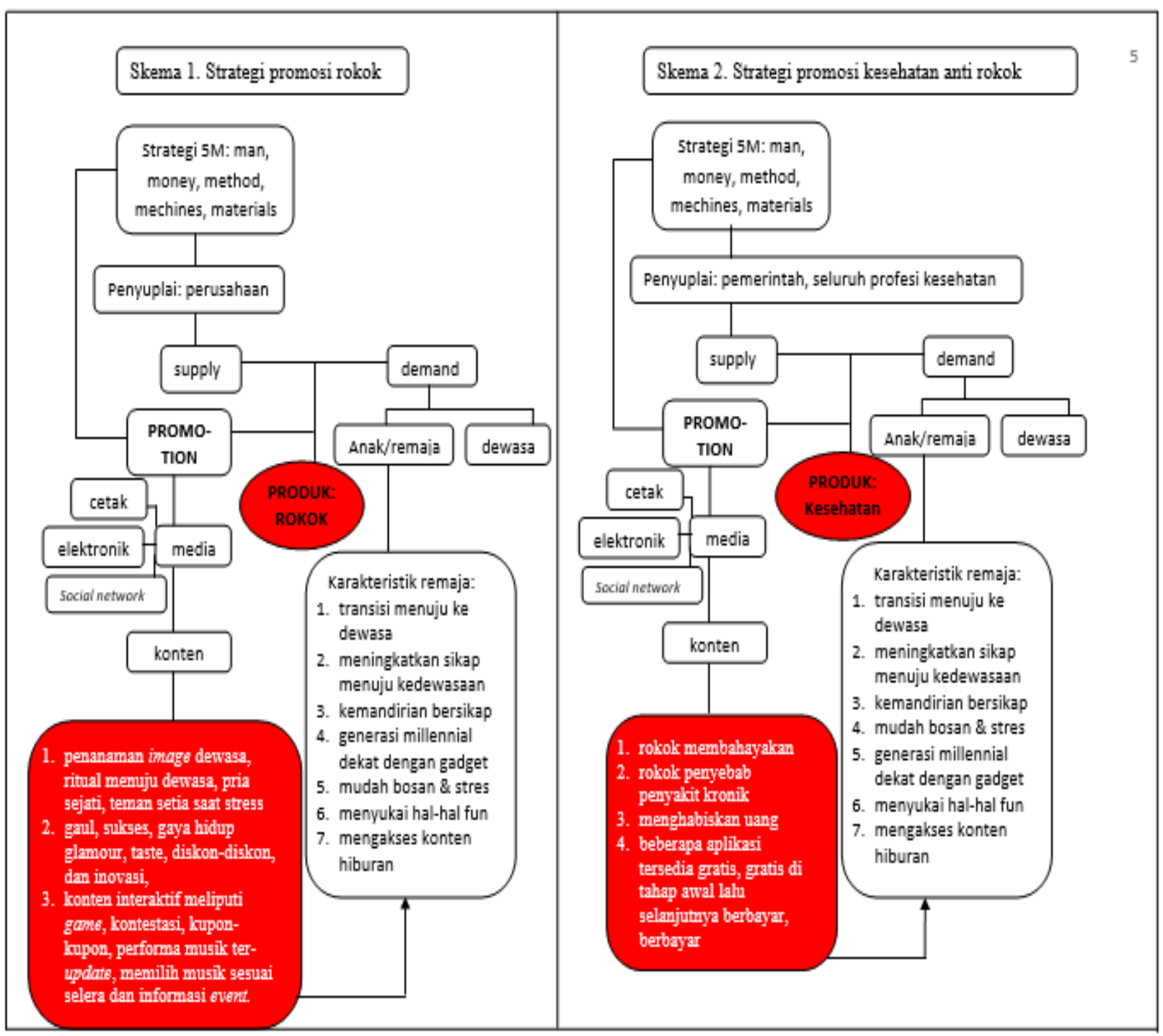

Sumber:

Dautzenberg B. (2018); Escobedo, et al (2018); Jackler, Li, Cardiff, dan Ramamurthi (2018); O’Brien, Navarro, dan Hoffman (2018); Bastonus \& Herieningsih (2017); Djamil (2017); Purnaningrum, Joebagio \& Murti (2017); Das, Tonelli, \& Ziedonis (2016); Lovelock \& Wirtz (2014).

Strategi promosi adalah bagian penting dalam manajemen pemasaran suatu produk. Lovelock \& Wirtz (2014) menguraikan ada lima pilar manajemen yang penting yakni man (orang), money (dana), method (metode), mechine (mesin) dan material (alat/bahan). Namun penulis membatasi bahasan pada pilar method yang lebih difokuskan pada strategi saja.

Dengan mengilustrasikan kesehatan dan rokok sebagai produk yang sejajar (lihat skema 1 dan 2) dan yang ingin 'dijual' ke masyarakat, maka kita akan mendapatkan gambaran seperti skema di atas. Skema dibuat untuk memudahkan dalam memahami dan menemukan kesenjangan antara kedua strategi. Dari skema tersebut tampak bahwa promosi kesehatan telah dilakukan dengan inovasi media yang digunakan yakni telah mengadopsi teknologi di dalamnya, meskipun belum masif. Perbedaan yang signifikan terlihat pada tema dan konten promosi yang disampaikan.

Perusahan rokok melakukan promosi dengan menggunakan konten penanaman nilai atau simbolisasi yang selaras dengan perkembangan psikologi remaja. Analisis terhadap konten promosi rokok ditemukan strategi pemasaran rokok mengusung tagline seperti My Life My Adventure, Go Ahead, My Style, Live Learn Lead,The Future Calls, Make It Your Journey, The Future Calls, Gak Ada Lo Gak Rame, Pria Punya Selera, dan lain-lain (Astuti, et al., 2019).

Tagline ini menyiratkan pesan yang relevan dengan perkembangan psikososial 
remaja. Erikson dalam teori perkembangan psikososialnya menguraikan remaja berada pada tahap pencarian identitas. Remaja mencoba berbagai perilaku yang didapat dari stimulus lingkungan, lalu memilihnya menjadi perilaku menetap atau mengeliminasinya (Miller, Vandome, and John, 2011). Semakin besar paparan stimulus, semakin mungkin bagi remaja untuk mencoba meniru dan selanjutnya menjadikan sebagai identitasnya.

Sejalan dengan hal tersebut, kegiatan marketing rokok dilakukan dengan berbagai cara, dilakukan massif dan terstruktur. Pemasaran rokok mengadopsi berbagai bentuk media, mulai dari media cetak, iklan televisi, media sosial hingga video game. Bahkan, pemasaranpun dilakukan dengan membagikan rokok secara gratis kepada remaja. Menurut data Global Youth Tobacco Survey (2019), terdapat 6\% remaja yang mengaku pernah ditawarkan rokok secara cumacuma oleh perusahaan rokok (World Helath Organization, 2020). Pemasaran yang dilakukan secara intens memberikan kesan bahwa merokok merupakan gaya hidup pria dewasa dan rokok bukan lah barang berbahaya.

Kontradiktif dengan hal tersebut, konten promosi kesehatan anti rokok berfokus pada informasi tentang penyakit atau peringatan tentang bahaya. Hal ini seperti tertuang dalam kebijakan pengendalian tembakau dengan menggunakan Peringatan Kesehatan Bergambar (PKB) sebagaimana tertuang dalam Peraturan Pemerintah Nomor 109 Tahun 2012 yang kemudian dijabarkan dalam Peraturan Menteri Kesehatan (PMK) Nomor 28 Tahun 2013 yang diberlakukan pada 24 Juni 2014 (Kemenkes RI, 2013; Presiden RI., 2012) .

Edukasi dengan mengedepankan bahaya terkesan menakut-nakuti dan dinilai tidak selalu relevan dengan perkembangan remaja. Hal ini ditemukan pada studi kualitatif yang menganalisis penggunaan PKB sebagai media promosi pencegahan merokok. hasil menunujukkan sebagian remaja memilih menghindar dari melihat PKB karena rasa takut (Rahmawati, Damayanti, dan Anshari, 2018). Diperkuat oleh studi yang senada, yakni ditemukan $44,6 \%$ remaja menutup PKB pada bungkus rokok dengan menggunakan stiker, $42,8 \%$ remaja merobek gambar, $36,7 \%$ memindahkan rokok ke tempat lainnya, dan mengabaikan PKB 27,7\% (Nurahmi, 2018).

Terkait penggunaan media promosi, beberapa promosi kesehatan anti rokok telah mengikuti perkembangan teknologi. Inovasi sudah dilakukan seperti menggunakan pesan text, facebook, twitter, instagram, situs web dan game.
Namun, aplikasi dan media yang ada belum masif menyasar kalangan remaja dan lebih ditargetkan sebagai dukungan bagi orang yang ingin berhenti merokok. Sedangkan perokok remaja masih tahap coba-coba atau pemula, yang biasanya belum berorientasi untuk berhenti.

Penggunaan media konvensional lebih mendominasi pada upaya promosi Perilaku Hidup Bersih Sehat (PHBS) termasuk pada pencegahan merokok. Media-media tersebut seperti leaflet, lembar balik, poster, modul, dan lain-lain, yang kerap digunakan petugas puskesmas atau dinas kesehatan saat ke sekolahsekolah. Upaya ini tidak berbeda dengan pembelajaran yang diterima remaja setiap hari di sekolah, dimana guru memberikan pembelajaran dengan metode ceramah atau diskusi dengan media-media seadanya.

Tantangan besar bagi seluruh praktisi kesehatan adalah bagaimana mengemas kesehatan menjadi issue yang menarik, menjadi kebutuhan bagi kaum remaja dan menggunakan pendekatan yang lebih inovatif. Hal ini sebagaimana direkomendasikan oleh Kusumawardani, Tarigan, Suparmi, \& Schlotheuber (2018), yakni strategi promosi anti rokok lebih spesifik mempertimbangkan usia, gender, status sosial ekonomi dan georgafi.

Mengatasi kesenjangan ini, penggunaan media inovatif dan kekinian menjadi keharusan. Berbagai aplikasi audiovisual dewasa ini banyak dikonsumsi kalangan remaja, seperti video game. Video game seharusnya menjadi peluang besar bagi upaya promosi kesehatan anti rokok dikarenakan identik dengan hal yang menyenangkan, kekinian, yang cocok dengan apa yang diminati kaum remaja. Penelitian Jap, Tiatri, Jaya, Suteja (2013) di Manado, Yogyakarta, Medan, dan Pontianak pada 1.477 pelajar ditemukankonsumsi video game di kalangan pelajar menghabiskan uang antara $\mathrm{Rp}$ 20.000,- sampai dengan Rp 200.000,- per minggu, dengan mayoritas durasi 2-3 hari per minggu dan setiap kali bermain menghabiskan 23 jam. Ini menunjukkan, memasukkan elemen promosi kesehatan dalam bentuk game dapat dimanfaatkan sebagai peluang promosi kesehatan.

Selain itu konten promosi tidak hanya difokuskan kepada bahaya, namun mengangkat sisi lainnya yang lebih diterima. Hal ini dalam rangka membuat kesehatan menjadi nilai bersama. 


\section{SIMPULAN}

Masalah merokok pada remaja merupakan poin krusial yang harus menjadi prioritas untuk ditangani. Strategi promosi kesehatan anti merokok telah up to date mengikuti perkembangan teknologi informasi dan komunikasi dalam hal penggunaan media. Namun penggunaannya belum masif dan keberhasilan penyampaian pesan promosi kesehatan sangat dipengaruhi oleh bagaimana cara mengemas pesan sehingga menjadi menarik dan dibutuhkan.

Meskipun tulisan ini masih dangkal karena hanya memandang dari sudur strategi pada

\section{DAFTAR PUSTAKA}

Allender, J., Rector, C., Rector, C., \& Warner, K. (2013). Community \& public health nursing: Promoting the public's health. Lippincott Williams \& Wilkins.

Astuti, P. A. S., Kurniasari, N. M. D., Mulyawan, K. H., Sebayang, S. K., dan Freeman, B. (2019). From glass boxes to social media engagement: an audit of tobacco retail marketing in Indonesia. Tobacco Control, tobacco control-2018054833. doi:10.1136/tobaccocontrol-2018054833

Badan Pusat Statistik. (2017). Survei Demografi Kesehatan Indonesia. Jakarta.

Bastonus, A. I. dan, \& Herieningsih, S. W. (2017). Hubungan Antara Terpaan Iklan Rokok dn Persepsi Maskulinitas Pada Perokok Dengan Perilaku Merokok Remaja Laki- Laki. Interaksi Online, 2l(1).

Borrelli, B., Bartlett, Y. K., Tooley, E., Armitage, C. J., \& Wearden, A. (2015). Prevalence and frequency of mHealth and eHealth use among US and UK smokers and differences by motivation to quit. Journal of Medical Internet Research. https://doi.org/10.2196/jmir.4420

Das, S., Tonelli, M., \& Ziedonis, D. (2016). Update on Smoking Cessation: ECigarettes, Emerging Tobacco Products Trends, and New Technology-Based Interventions. Current Psychiatry Reports, 18(5). https://doi.org/10.1007/s11920-0160681-6

Dautzenberg, B., \& Dautzenberg, M. D. (2018). Systematic analysis of the scientific literature on heated tobacco. Revue des maladies respiratoires, 36(1), 82-103. media, namun temuan dari telaah ini patut untuk dipertimbangkan. Bukan pekerjaan mudah untuk membangun kesadaran dan merubah perilaku remaja, namun bila seluruh praktisi kesehatan berupaya bersama dan saling bersinergi, diharapkan berdampak lebih baik. Game merupakan fitur audiovisual yang dapat dimanfaatkan dalam upaya mempromosikan nilai-nilai kesehatan kepada masyarakat. Diharapkan pada masa yang akan datang, promosi kesehatan dalam kemasan fitur-fitur game lebih dikembangkan, karena mudah diakses, inovatif, relevan dan kekinian.

Djamil, M. (2017). Gaya hidup perokok dalam bingkai foto. [Skripsi]. Makassar: Fakultas Dakwah dan Komuniksi, Universitas Islam Alauddin Makassar. http://repositori.uin-alauddin.ac.id/14651/

Escobedo, P., Cruz, T. B., Tsai, K. Y., Allem, J. P., Soto, D. W., Kirkpatrick, M. G., ... Unger, J. B. (2018). Monitoring Tobacco Brand Websites to Understand Marketing Strategies Aimed at Tobacco Product Users and Potential Users. Nicotine \& Tobacco Research: Official Journal of the Society for Research on Nicotine and Tobacco, 20(11), 1393-1400. https://doi.org/10.1093/ntr/ntx200

Fernández-de-Arroyabe-Olaortua, A., LazkanoArrillaga, I., \& Eguskiza-Sesumaga, L. (2018). Digital natives: Online audiovisual content consumption, creation and dissemination. Comunicar, 26(57), 61-69.

Haug, S., Paz Castro, R., Wenger, A., \& Schaub, M. P. (2018). Efficacy of a mobile phonebased life-skills training program for substance use prevention among adolescents: study protocol of a clusterrandomised controlled trial. BMC Public Health, 18(1), 1102. https://doi.org/10.1186/s12889-018-5969-5 Jackler, R. K., Li, V. Y., Cardiff, R. A. L., \& Ramamurthi, D. (2018). Promotion of tobacco products on Facebook: Policy versus practice. Tobacco Control, (February), 1-7. https://doi.org/10.1136/tobaccocontrol2017-054175

Jacobs, M. A., Cobb, C. O., Abroms, L., \& Graham, A. L. (2014). Facebook apps for smoking cessation: A review of content 
and adherence to evidence-based guidelines. Journal of Medical Internet Research, 16(9), 1-6. https://doi.org/10.2196/jmir.3491

Jap, T., Tiatri, S., Jaya, E. S., \& Suteja, M. S. (2013). The development of Indonesian online game addiction questionnaire. PloS one, 8(4), e61098.

Kemenkes RI. (2013). Peraturan Menteri Kesehatan Nomor 28 Tahun 2013 tentang Pencatuman Peringatan Kesehatan da Informasi Kesehatan pada Kemasan Produk Tembakau. Jakarta.

Kotler, P., \& Armstrong, G. (2012). Principles of marketing 14th edition. New Jearsey: Pearson Education Inc.

Kusumawardani, N., Tarigan, I., Suparmi, \& Schlotheuber, A. (2018). Socio-economic, demographic and geographic correlates of cigarette smoking among Indonesian adolescents: results from the 2013 Indonesian Basic Health Research (RISKESDAS) survey. Global Health Action, 11(1). https://doi.org/10.1080/16549716.2018.14 67605

Lovelock, C., \& Wirtz, J. (2014). Services Marketing: People, Technology, Strategy. In Pearson. https://doi.org/10.1044/10590889(2011/10-0028)

Miller, Vandome, John. (2011). Erikson's of Psychosocial Development. Germany: VDM Publishing

Nebhinani, N., \& Kuppili, P. P. (2018). Prevention of substance use in children and adolescents. Journal of Indian Association for Child and Adolescent Mental Health, 14(2),1-11. https://doi.org/10.1002/9780470753385.ch 21

Nurahmi, Leni dan Damayanti, Rita. (2018). Respon perokok remaja terhadap peringatan kesehatan bergambar di bungkus rokok. Perilaku dan Promosi Kesehatan, Vol. 1, No. 1, April 2018: 63 75.

O’Brien, E. K., Navarro, M. A., \& Hoffman, L. (2018). Mobile website characteristics of leading tobacco product brands: Cigarettes, smokeless tobacco, e-cigarettes, hookah and cigars. Tobacco Control, 1-8. https://doi.org/10.1136/tobaccocontrol2018-054549

Presiden RI. (2012). Peraturan Pemerintah Nomor 109 Tahun 2012 tentang Pengamanan Bahan yang Mengandung Zat Adiktif berupa Produk Tembakau bagi
Kesehatan. Jakarta.

Purnaningrum, Joebagio, dan, \& Murti, B. (2017). Association Between Cigarette Advertisement, Peer Group, Parental Education, Family Income, and Pocket Money with Smoking Behavior among Adolescents in Karanganyar District, Central Java. Journal of Health Promotion and Behavior, 02(02), 148-158. https://doi.org/10.26911/thejhpb.2017.02.0 2.05

Rahmawati, A. A. D., Damayanti, R., \& Anshari, D. (2018). Persepsi remaja terhadap kesan menakutkan pada peringatan kesehatan bergambar di bungkus rokok ditinjau dari Extended Parallel Process Model. Perilaku dan Promosi Kesehatan, 1(1), 10-22.

Raiff, B. R., Fortugno, N., Scherlis, D. R., \& Rapoza, D. (2018). A mobile game to support smoking cessation: Prototype assessment. Journal of Medical Internet Research, 20(6), 1-11. https://doi.org/10.2196/games.9599

Shabalina, O., Aleynikov, V., Davtian, A., Matokhina, A., \& Moffat, D. C. (2017). "don't make me an orphan, mom": A mobile game to support smoking cessation. Proceedings of the International Conference on E-Health, EH 2017 - Part of the Multi Conference on Computer Science and Information Systems 2017, 6370.

Spohr, S. A., Nandy, R., Gandhiraj, D., Vemulapalli, A., Anne, S., \& Walters, S. T. (2015). Efficacy of SMS Text Message Interventions for Smoking Cessation: A Meta-Analysis. Journal of Substance Abuse Treatment, 56, 1-10. https://doi.org/10.1016/j.jsat.2015.01.011

Tan YL. and Dorotheo. (2018). The tobacco control atlas: ASEAN Region (fourth Edi). https://seatca.org/clove-cigarettes-mayprompt-u-s-indonesia-dispute/

Wang, C., Hipp, J. R., Butts, C. T., \& Lakon, C. M. (2018). The interdependence of cigarette, alcohol, and marijuana use in the context of school-based social networks. PLoS ONE, 13(7), 1-22. https://doi.org/10.1371/journal.pone.02009 04

World Helath Organization, R. O. for S.-E. A. (2015). Global Youth Tobacco Survey ( GYTS ) Indonesia Report 2014. New Delhi: WHO-SEARO.

World Helath Organization. (2016). TOBACCO USE IN. (March), 2014-2017. 
World Health Organization. (2017). WHO Report Organization. on the global tobacco epidemic: Monitoring tobacco use and prevention policies. Switzerland: World Health

World Helath Organization. (2020). Global Youth Tobacco Survey (GYTS). Bhutan. 